\title{
The Influence of Irrigation Frequency on the Onset and Development of Verticillium Wilt of Olive
}

\author{
M. Pérez-Rodríguez, E. Alcántara, and M. Amaro, Departamento de Agronomía, Universidad de Córdoba, Campus Universitario de \\ Rabanales, Edificio Celestino Mutis (C4), 14071, Córdoba, Spain; N. Serrano, I. J. Lorite, and O. Arquero, IFAPA, Centro 'Alameda \\ del Obispo', 14080 Córdoba, Spain; F. Orgaz, Instituto de Agricultura Sostenible, Consejo Superior de Investigaciones Científicas (CSIC), \\ Apartado 4084, 14080, Córdoba, Spain; and F. J. López-Escudero, Departamento de Agronomía, Universidad de Córdoba, Campus \\ Universitario de Rabanales.
}

\begin{abstract}
Pérez-Rodríguez, M., Alcántara E., Amaro, M., Serrano, N., Lorite, I. J., Arquero, O., Orgaz, F., and López-Escudero, F. J. 2015. The influence of irrigation frequency on the onset and development of verticillium wilt of olive. Plant Dis. 99:488-495.

The influence of irrigation frequency on the onset and development of Verticillium wilt of olive (VWO) was studied. A split-plot design in microplots with naturally infested soil was established for studying four irrigation frequencies for three olive cultivars with differing levels of disease resistance. Final disease incidence (DI) and mortality in 'Picual' plants subjected to daily irrigation treatment (T1) reached values of 100 and $63 \%$, respectively. For Picual-T1 samples, the area under the disease progress curve values were significantly different between 15 December 2012 and 15 July 2013 (14.8 to $42.8 \%$ ) compared with the average results of the other treatments, which were

weekly (T2), biweekly (T3), and deficit (T4) (0.4 to 11.5\%). No significant differences between the irrigation treatments were observed in 'Arbequina', although the DI progressed consistently (60\% in all treatments). In 'Frantoio', little disease developed. We conclude that a daily irrigation treatment encourages VWO development in susceptible Picual. Therefore, in susceptible cultivars growing in infested soils under daily irrigation regimes, the extension of irrigation frequency may reduce disease incidence. In the context of an integrated control, the use of resistant cultivars seems to be more relevant than the detrimental effects observed in frequent irrigation schedules.
\end{abstract}

The occurrence of vascular wilts due to the soilborne pathogen Verticillium dahliae Kleb. are particularly correlated with the irrigation regimes of many of their hosts, such as potato (Arbogast et al. 1999), tomato (Harrington and Dobinson 2000), or cotton (Blanco-López and De Vay 1987; Huisman and Grimes 1989). In olive, this pathogen causes Verticillium wilt of olive (VWO), a vascular disease that kills thousands of young and producing trees annually in the major areas of olive oil and table olive production around the world (Bubici and Cirulli 2011; López-Escudero and Mercado-Blanco 2011, 2012; Tsror 2011). In the Guadalquivir Valley of Andalucía (southern Spain), where nearly 900,000 ha of this commodity are planted (Anonymous 2013), the disease incidence (DI) and prevalence significantly increases when orchards are reconverted from dry lands to irrigated zones (López-Escudero et al. 2010; Rodríguez et al. 2008).

Irrigation water collected from wells or delivered from pumping stations and used for watering olive orchards is an important means of dispersal of the infectious forms of this pathogen (García-Cabello et al. 2012; Rodríguez Jurado and Bejarano Alcázar 2007). Moreover, López-Escudero and Blanco-López (2005) have previously demonstrated that drip irrigation results in an increase in the abundance of this pathogen in the soil. In this study, we found that fungal populations in the soil were greater and increased at a faster rate over time in the wet zones surrounding the drippers compared with the dry areas away from them.

In this context, olive growers and agronomists assume that increasing irrigation dosages or shortening irrigation frequencies provides some protection against Verticillium wilt onset and decreases severity. This has been previously reported in some woody hosts, such us maple (Shufelt and Linderman 1986). However, there is no scientific evidence as to how this agricultural practice affects disease prevalence and severity in olive.

Corresponding author: M. Pérez-Rodríguez; E-mail: marioagro25@hotmail.com Accepted for publication 27 October 2014.

http://dx.doi.org/10.1094/PDIS-06-14-0599-RE

(C) 2015 The American Phytopathological Society
In this work, we studied the influence of irrigation frequency on the onset and development of VWO. Experiments were conducted in microplots using soil that was naturally infested with the pathogen.

\section{Materials and Methods}

Experimental plot. The experiment was conducted under semicontrolled conditions in a plot located in Campus de Rabanales (Universidad de Córdoba, Spain) during the period December 2011 to October 2013. This plot consisted of a line of 40 concrete containers located above ground. Each plot was $1 \mathrm{~m}^{2}$ by $70 \mathrm{~cm}$ deep, open at the bottom, oriented north to south, and protected from rain and excessive sun by a galvanized steel cover. The microplots were filled with a soil that was naturally infested with $V$. dahliae The microplots were planted with different olive cultivars and irrigated with several different irrigation frequencies, as explained below.

Collecting and characterizing the soil naturally infested with $\boldsymbol{V}$. dahliae. The naturally infested soil was collected from a field located in the municipality of Utrera (Sevilla, southern Spain) in a marsh area annually cropped with $V$. dahliae hosts. In this zone, soils are heavily infested with highly virulent strains of $V$. dahliae (cottondefoliating pathotype) (Bejarano-Alcázar et al. 1996) and VWO incidence and mortality develops quickly (Trapero et al. 2013).

To assess the fungal population in the selected plot, approximately 40100 -g soil samples were collected from a depth of 25 to $30 \mathrm{~cm}$ using a cylindrical soil auger. Subsamples were bulked, crumbled, and mixed. The resulting soil samples were then air dried for 4 weeks at room temperature. Following the drying period, samples were sieved through a $0.8-\mathrm{mm}$ sieve to remove organic debris and larger particles. Samples were then mixed manually and air dried for an additional 1 to 2 weeks. The inoculum density (ID) of $V$. dahliae was estimated using the wet-sieving-technique described by Huisman and Ashworth (1974). A sample aliquot of $25 \mathrm{~g}$ was suspended in $100 \mathrm{ml}$ of distilled water, shaken for $1 \mathrm{~h}$ at $270 \mathrm{rpm}$, and filtered through 150- and 35$\mu \mathrm{m}$ sieves. The residue retained in the $35-\mu \mathrm{m}$ sieve was recovered in $100 \mathrm{ml}$ of distilled water. Finally, $1 \mathrm{ml}$ of the suspension was plated onto a modified sodium polypectate agar medium (Butterfield and DeVay 1977) with 10 replicates. After a 14-day incubation at $22 \pm 2{ }^{\circ} \mathrm{C}$ in the dark, soil residues were removed with tap water and colonies of $V$. dahliae were counted under a stereoscope microscope. 
The ID in the soil was estimated using the number of colonies of $V$. dahliae observed and expressed as propagules or microsclerotia (MS) per gram of air-dried soil. A highly infested soil (21 MS/g) was chosen for the experiment.

The isolation and molecular characterization of the pathogens in the soil used for the experiment were conducted using the methodology described by López-Escudero and Blanco-López (2005) and Mercado-Blanco et al. (2003). This analysis revealed that highly virulent strains of $V$. dahliae (defoliating pathotype) were prevalent in the soil.

Soil properties. The soil used for planting was a clay soil $(\mathrm{pH}$ in $\mathrm{ClK}=7.45$, organic matter $=1.57 \%$, total $\mathrm{CaCO}_{3}$ equivalent $=$ $25.64 \%$, active $\mathrm{CaCO}_{3}=3.33 \%$, available $\mathrm{K}=475 \mathrm{ppm}$, and available $\mathrm{P}=8.4 \mathrm{ppm}$ ). The soil was repeatedly cultivated in previous years with cotton, tomato, and alfalfa and surrounded by plots with similar crops.

To determine the hydraulic properties of the soil, a 12-liter plastic pot filled with soil was watered to saturation and covered with a black plastic film to avoid evaporation. After the water was freely drained, the plastic pot was weighed and dried in an oven at $70^{\circ} \mathrm{C}$ for 7 days. The pot was then weighed to determine the mass of water and the mass of soil solid. The upper limit soil water content $\left(\theta_{\mathrm{UL}}\right)$ was determined according to the gravimetric method using the following formula: $\theta_{\mathrm{UL}}=\left(\mathrm{V}_{\mathrm{w}}\right) /\left(\mathrm{V}_{\mathrm{s}}\right)$, where $\mathrm{V}_{\mathrm{w}}=$ the mass of water and $\mathrm{V}_{\mathrm{s}}=$ the total volume of soil. The $\theta_{\mathrm{UL}}$ value calculated for this soil was $0.37 \mathrm{~m}^{3} \mathrm{~m}^{-3}$

The available water in this soil was also assessed by measuring the lower limit of the soil water content $\left(\theta_{\mathrm{LL}}\right)$. To calculate this variable, barley seed were sown in a 12-liter plastic pot filled with soil. When the plants reached maximum vegetative growth, the irrigation was cut. After plants had died, the soil water content was determined using the above formula. The $\theta_{\mathrm{LL}}$ value calculated for this soil was $0.17 \mathrm{~m}^{3} \mathrm{~m}^{-3}$.

Plant material. Nine-month-old rooted olive cuttings of cultivars with differing levels of resistance to infections caused by $V$. dahliae were used in the experiment. The cultivars used were as follows: 'Picual' (susceptible to disease), 'Arbequina' (moderately susceptible) and 'Frantoio' (resistant) (López-Escudero et al. 2004; Martos-Moreno et al. 2006). The cuttings were clones of each cultivar. These were obtained from certificated mother olive plants free of pathogen infection from the World Olive Germplasm Bank (Caballero and Del Río 2008) from IFAPA, Centro 'Alameda del Obispo', Córdoba, Spain, and propagated according to Caballero and Del Río (2010).

At the beginning of the experiment, plants were 0.5 to $0.7 \mathrm{~m}$ high, with a single trunk and two or three secondary branches. The initial leaf area and aerial biomass of the plants were $297.1 \mathrm{~cm}^{2} /$ plant and $11.7 \mathrm{~g} /$ plant, respectively, for Picual plants; $283.2 \mathrm{~cm}^{2} /$ plant and $12.6 \mathrm{~g} /$ plant, respectively, for Arbequina plants; and $200 \mathrm{~cm}^{2} /$ plant and $12.5 \mathrm{~g} /$ plant, respectively, for Frantoio plants.

Irrigation treatments. For this experiment, the following four irrigation frequencies were analyzed: daily (T1), weekly (T2), biweekly (T3), and deficit (T4). Irrigation scheduling (see below) was calculated using the relative soil water deficit (RSWD) parameter according to the following formula: RSWD $=\left(\theta_{\mathrm{UL}}-\theta_{\mathrm{i}}\right) /\left(\theta_{\mathrm{UL}}-\theta_{\mathrm{LL}}\right)$, where $\theta_{\mathrm{i}}$ is the volumetric soil water content. For the T1, T2, and T3 treatments, the RSWD parameter was generally $<0.9$. For the $\mathrm{T} 4$ treatment, the RSWD parameter was generally $\geq 0.9$. For this treatment, irrigation frequencies were greater in the spring and summer (approximately 20 days) and lower in the winter (approximately 40 days).

Microplot establishment and experimental design. In October 2011, approximately 36 tons of the collected soil was carried from the Utrera Marsh to the experimental plot in Rabanales. The soil was homogenized by continuous crumbling and mixing using a tractor shovel at the experiment site. Each microplot was filled with $800 \mathrm{~kg}$ of soil (bulk density $=1,300 \mathrm{~kg} / \mathrm{m}^{3}$ ). For the noninfested control microplots, the soil was sterilized.

Olive plants were transplanted in December 2011. A split-plot design was used. Three microplots per cultivar and watering treatment were used, with nine plants per microplot. Two noninfested control microplots, irrigated according to the $\mathrm{T} 1$ treatment, were assigned to each cultivar.

Plants were drip irrigated using a programmable irrigation controller (Image 6 Rain Bird; Rain Bird Iberica S.A., Spain) connected to a PVC water pipe (50 $\mathrm{mm}$ in diameter and $40 \mathrm{~m}$ long) extended along the container line. For each microplot, a stopcock, six branch lines (16 $\mathrm{mm}$ in diameter and $80 \mathrm{~cm}$ in length, with $16.5-\mathrm{cm}$ spacing), and 36 compensating drippers (2 liters/h, 6 per branch) (Netafim) were connected to the pipe.

Soil water content measurement in the microplots. The soil water content in each microplot was recorded every 15 days using a time domain reflectometry system $(6050 \times 1$ Trase System I; Soil Moisture Equipment Corp., Santa Barbara, CA). Data were used for planning an irrigation schedule that was individually calculated for each treatment and microplot. The volumetric water content of each container (RSWD level) was maintained corresponding to its irrigation treatment.

ID of $V$. dahliae in microplot soil. The ID of the pathogen in the soil was assessed just before and at the end of the experiment for all individual microplots and for all treatments. A 100-g soil sample was taken from the 0 - to $25-\mathrm{cm}$ depth profile from each container using a cylindrical auger. The ID was quantified using the method described above.

Disease progression and tree development. The experimental plot was surveyed periodically for 22 months after planting for disease symptoms, particularly during the most favorable environmental periods for disease development (for our conditions, these periods were spring, early summer, and fall). Disease severity was estimated based on a 0-to-4 rating scale according to the percentage of plant tissue affected by any of the following symptoms: chlorosis, necrosis, or defoliation $(0=$ no symptoms; $1=1$ to $33,2=34$ to 66 , and $3=67$ to $99 \%$ affected tissue; and $4=$ dead plant). These values were used to build the progress curves for the DI of the affected plants and the mean severity of the symptoms over time during the recording period. Curves of mean severity over time were adjusted to the logistic model.

$$
y_{L}(t)=\rho_{1} /\left\{1+\exp \left[-\left(\rho_{2}+\rho_{3} t\right)\right]\right\}
$$

The parameter $\rho_{1}$ is the upper asymptote, $\rho_{2}$ is related to initial level of disease severity, and $\rho_{3}$ is the rate of the process (Hau et al. 1993, Navas-Cortés et al. 2008).

For these curves, the maximum disease progress rate (MDPR) (the slope of the tangent line at the inflection point of the curve) was calculated as described by Moral and Trapero (2009). Moreover, the time elapsed between plantation establishment and when $50 \%$ of diseased trees (DI50), 50\% of dead trees (M50), and 50\% of the maximum values of disease severity (value $=2)($ MS50) were reached was also calculated for each treatment.

At the end of the experiment, the area under the disease progress curve (AUDPC) was estimated as the percentage of the maximum possible value in the considered period according to the following formula based, on Campbell and Madden (1990): AUDPC = $[(t / 2 \times(\mathrm{S} 2+2 \times \mathrm{S} 3+\ldots+2 \mathrm{Si}-1+\mathrm{Si}) / 4 \times n] \times 100$, where $t=$ the interval in days between observations, $\mathrm{Si}=$ the final mean severity, $4=$ the maximum disease rating, and $n=$ the number of observations. This value was also calculated for three other recording times during the assessment period in which the interaction between the irrigation treatment frequency and cultivar became significant.

The final percentage of dead plants, or mortality (M), was also considered in estimating the severity of the reactions. The time that elapsed from transplanting to the onset of disease symptoms (FS) and the mean mortality time (MM) (mean time between the onset of disease symptoms and plant death) was determined for all irrigation-cultivar treatments.

To avoid the incorporation of new inoculum into the soil, falling leaves and dried plant debris from dead shoots and buds from affected plants in infested microplots due to slow decline caused by pathogen infection (López-Escudero and Mercado-Blanco 2011) were removed periodically from the surface of the microplots.

Pathogen isolation. Plant infection was confirmed by isolating the fungus from the affected shoots or leaf petioles of diseased plants. 
Affected woody tissue samples were washed in running tap water and the bark was removed. The tissue surface was then disinfected in $0.5 \%$ sodium hypochlorite for $1 \mathrm{~min}$. Wood chips were placed on potato dextrose agar (PDA) plates and incubated at $24^{\circ} \mathrm{C}$ in the dark for 6 days. When affected tissues did not yield detectable pathogen cultures, shoot tissues were analyzed using polymerase chain reaction methods, as described by Mercado-Blanco et al. (2003).

Data analysis. In this trial, an analysis of variance (ANOVA) of the parameters was performed using the Statistix 10.0 software program (Analytical Software, Tallahassee, FL). The mean values of the analyzed parameters were compared using Fisher's protected least significant difference test at $P=0.05$.

To determine whether there was significant interaction between the irrigation frequencies and the cultivars, an ANOVA was performed using the most representative disease parameter, AUDPC, as the dependent variable. Data were analyzed in a split-plot design, with the irrigation frequency as the main plot and the cultivars as the subplot. MM and FS parameters were analyzed using nonparametric Kaplan-Meier survival analysis (Kaplan and Meier 1958), in which the survival times were calculated as the week in which a plant died or showed disease symptoms for the first time. Pairwise comparisons were tested using the log-rank test at $P=0.05$ and performed using the SPSS software program (Statistical, Package for Social Sciences; SPSS Inc., Chicago). Nonlinear regression analyses were conducted using the mentioned Statistix 10 software. A pseudo- $R^{2}$ parameter was used to evaluate the appropriateness of the logistic model to describe the data.

\section{Results}

ID of $\boldsymbol{V}$. dahliae in the soil. Soil analyses of ID at a depth of $20 \mathrm{~cm}$ revealed that pathogen MS were present in all microplots at the two recording times. ID in the container soil was homogeneous, with an average value of $9.8 \mathrm{MS} / \mathrm{g}$. No significant differences were detected in the initial and final amounts of soil pathogens between microplots with different irrigation treatments and different cultivars.

Disease symptoms. During the experiment, the affected plants exhibited slow decline (López-Escudero and Mercado-Blanco 2011). During the fall and early spring, plants showed chlorosis, dieback, and rolling of the leaves without the defoliation of green leaves.
Necrosis and desiccation in flowers mainly occurred during the second year of observation in Picual and Arbequina trees. Defoliation and sudden wilt were frequently observed together in Picual under T1 treatment.

Pathogen isolation from affected tissues. Tissues from the stems of all plants exhibiting foliar symptoms produced $V$. dahliae upon culturing on PDA after 3 or 4 days of incubation. Almost all isolates recovered from symptomatic plants corresponded to the defoliating pathotype of the pathogen.

Disease progression. The first symptomatic plant was recorded in Picual-T1 just 20 weeks after planting. In October 2012, 45 weeks after tree establishment, disease symptoms were observed affecting several plants of Picual and Arbequina (Table 1). The onset of symptom development was first observed in the daily-irrigated (T1) microplots planted with susceptible Picual trees. The appearance of first symptoms was significantly earlier in Picual plants under this treatment (an average of 46 weeks) compared with Picual plants under other treatments and Arbequina and Frantoio plants, where differences were not detected (from 69 to 78 weeks) (Table 1).

During fall 2012, a serious epidemic developed in Picual plants under T1 treatment; DI values reached $80 \%$ in 4 weeks (from 15 September to 15 November) (Fig. 1). By this time, the DI in other Picual irrigation treatments (T2, T3, and T4) did not reach values greater than $20 \%$ (Fig. 1).

At the end of the assessment period, the DI in Picual plants under T1 treatment reached $100 \%$. For other treatments, DI for this cultivar remained below $67 \%$ (Table 1). The 50\% DI (DI50) was reached earlier in trees under T1 treatment (41 weeks) than for trees subjected to other irrigation treatments (average of 76 weeks) (Table 2). Similar progression, in the parameters MS50 and M50 were observed for the Picual-T1 treatment (Table 2). The mean time from symptom onset to plant death was significantly shorter in trees under the treatments T1 and T3 (44.1 and 47.0 weeks, respectively) than for plants under T2 and T4 treatments (73.9 and 68.1 weeks, respectively) (Table 1). The percentage of trees killed by the pathogen in T1 was $63 \%$ after 22 months.

The AUDPC ANOVA demonstrated that the interaction between the irrigation treatment and the cultivar was significant $(P<0.05)$ between 15 December 2012 and 15 July 2013. For this period, each cultivar was studied separately.

Table 1. Effect of irrigation frequency on the final estimated disease values for three cultivars of olive trees (Picual, Arbequina, and Frantoio) in microplots of soil naturally infested by Verticillium dahliae ${ }^{\mathrm{u}}$

\begin{tabular}{|c|c|c|c|c|c|c|c|}
\hline \multirow[b]{2}{*}{ Cultivar, treatments } & \multicolumn{2}{|c|}{ FS $\left(\right.$ weeks) ${ }^{\mathrm{v}}$} & \multirow[b]{2}{*}{ Mortality $(\%)^{\mathrm{w}}$} & \multirow[b]{2}{*}{$\mathbf{M S}^{\mathbf{x}}$} & \multirow[b]{2}{*}{ Incidence (\%) } & \multirow[b]{2}{*}{ MS affected plants ${ }^{y}$} & \multirow[b]{2}{*}{ MM (weeks) ${ }^{\mathrm{z}}$} \\
\hline & Range & Mean & & & & & \\
\hline \multicolumn{8}{|l|}{ Picual } \\
\hline T1 (daily) & $20-77$ & $46 \mathrm{a}$ & $62.9 \mathrm{a}$ & $3.5 \mathrm{a}$ & $100 \mathrm{a}$ & $3.5 \mathrm{a}$ & $44.1 \mathrm{a}$ \\
\hline T2 (weekly) & $41-93$ & $77 \mathrm{~b}$ & $37.0 \mathrm{a}$ & $1.8 \mathrm{a}$ & $62.9 \mathrm{a}$ & $3.1 \mathrm{a}$ & $73.9 \mathrm{~b}$ \\
\hline T3 (biweekly) & $45-93$ & $75 \mathrm{~b}$ & $59.2 \mathrm{a}$ & $2.5 \mathrm{a}$ & $66.6 \mathrm{a}$ & $3.7 \mathrm{a}$ & $47.0 \mathrm{a}$ \\
\hline $\mathrm{T} 4$ (deficit) & $51-81$ & $78 \mathrm{~b}$ & $29.6 \mathrm{a}$ & $1.6 \mathrm{a}$ & $59.2 \mathrm{a}$ & $2.9 \mathrm{a}$ & $68.1 \mathrm{~b}$ \\
\hline Mean & $\ldots$ & 69 & 47.2 & $2.3 \mathrm{a}$ & $72.2 \mathrm{a}$ & $3.3 \mathrm{a}$ & $\ldots$ \\
\hline \multicolumn{8}{|l|}{ Arbequina } \\
\hline T1 (daily) & $45-93$ & $76 \mathrm{~b}$ & $\ldots$ & $1.0 \mathrm{a}$ & $59.3 \mathrm{a}$ & $1.4 \mathrm{a}$ & $\ldots$ \\
\hline T2 (weekly) & $45-77$ & $74 \mathrm{~b}$ & $\ldots$ & $0.9 \mathrm{a}$ & $55.5 \mathrm{a}$ & $1.5 \mathrm{a}$ & $\ldots$ \\
\hline T3 (biweekly) & $45-72$ & $69 \mathrm{~b}$ & 3.7 & $1.5 \mathrm{a}$ & $59.3 \mathrm{a}$ & $2.5 \mathrm{a}$ & $89.0 \mathrm{c}$ \\
\hline $\mathrm{T} 4$ (deficit) & $41-77$ & $70 \mathrm{~b}$ & 3.7 & $1.3 \mathrm{a}$ & $59.3 \mathrm{a}$ & $1.9 \mathrm{a}$ & $88.9 \mathrm{c}$ \\
\hline Mean & $\ldots$ & 72.2 & 1.8 & $1.2 \mathrm{~b}$ & $58.3 \mathrm{a}$ & $1.8 \mathrm{~b}$ & $\ldots$ \\
\hline \multicolumn{8}{|l|}{ Frantoio } \\
\hline T1 (daily) & $57-93$ & $75 \mathrm{~b}$ & $\ldots$ & $0.3 \mathrm{a}$ & $25.9 \mathrm{a}$ & $0.6 \mathrm{a}$ & $\ldots$ \\
\hline T2 (weekly) & 74 & $74 \mathrm{~b}$ & $\ldots$ & $0.1 \mathrm{a}$ & $3.7 \mathrm{a}$ & $0.3 \mathrm{a}$ & $\ldots$ \\
\hline T3 (biweekly) & $55-93$ & $74 \mathrm{~b}$ & 3.7 & $0.2 \mathrm{a}$ & $7.4 \mathrm{a}$ & $1.4 \mathrm{a}$ & 17 \\
\hline $\mathrm{T} 4$ (deficit) & $65-81$ & $73 \mathrm{~b}$ & $\ldots$ & $0.1 \mathrm{a}$ & $7.4 \mathrm{a}$ & $0.7 \mathrm{a}$ & $\ldots$ \\
\hline Mean & $\ldots$ & 74 & 0.9 & $0.2 \mathrm{c}$ & $11.1 \mathrm{~b}$ & $0.7 \mathrm{c}$ & $\ldots$ \\
\hline
\end{tabular}

u Trees were surveyed every 2 weeks for symptom development over 22 months (December 2011 to October 2013). Values listed in columns followed by the same letter were not significantly different at $P=0.05$

${ }^{v} \mathrm{FS}=$ the time from tree transplantation to the onset of disease symptoms. Differences were estimated according to the log rank test.

${ }^{\mathrm{w}}$ Mortality $(\%)=$ differences were estimated according to Fisher's protected least significant difference (LSD) test.

${ }^{x}$ MS $=$ mean severity. Differences were estimated according to Fisher's protected LSD test.

${ }^{\text {y }}$ MS affected plants = Mean severity of symptomatic plants. Differences were estimated according to Fisher's protected LSD test.

${ }^{\mathrm{z}} \mathrm{MM}=$ time from symptom onset to plant death. Differences were estimated according to the log rank test. 
Picual trees that were irrigated daily (T1) reached AUDPC values of $14.8 \%$ on 15 December; on average, Picual trees under the remaining treatments reached AUDPC values of $0.4 \%$. Significant differences continued past this date, because AUDPC was $42.8 \%$ for T1 compared with an average of $11.5 \%$ for T2, T3, and T4. From October 2013 onward, the differences were not statistically significant (Table 2; Fig. 2).

Significant differences in disease progression in affected trees and in any of the investigated phytopathological parameters in the Arbequina trees subjected to different irrigation treatments were not detected during the observation period. The onset of symptom development occurred at 72.2 weeks after plantation. In this cultivar, disease onset in the four irrigation treatments also began during fall 2012 and progressed at a moderate rate that was similar between treatments (Tables 1 and 3; Figs. 1 and 2). The pathogen caused disease symptoms in $60 \%$ of trees following the observation period. These plants exhibited low mean severity values (an average of 1.2 ), and only $1.8 \%$ of trees died (Table 1 ). The DI50 value recorded for Arbequina plants was higher than that registered for Picual plants (Table 3). No significant differences were detected in the AUDPC values during the observation period among the different irrigation treatments.
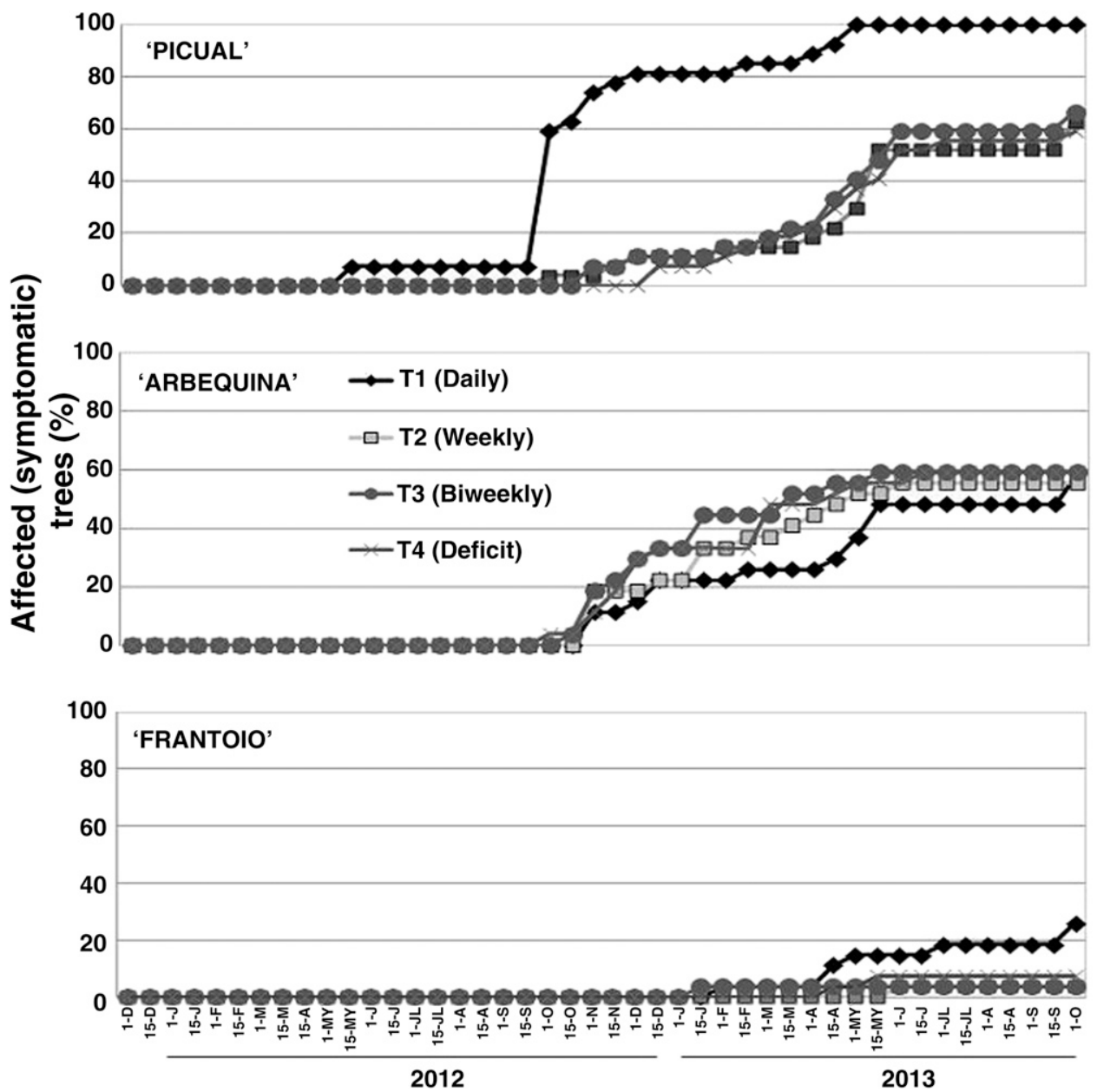

Fig. 1. Verticillium wilt disease incidence over time in Picual (susceptible), Arbequina (moderately susceptible), and Frantoio (resistant) olive in microplots of soil naturally infested with Verticillium dahliae and subjected to four irrigation frequencies: daily (T1), weekly (T2), biweekly (T3), and deficit (T4).

Table 2. Progression of the disease parameters for Picual olive trees in microplots of soil naturally infested with Verticillium dahliae and subjected to different irrigation frequencies ${ }^{\mathrm{u}}$

\begin{tabular}{|c|c|c|c|c|c|c|c|c|}
\hline \multirow[b]{2}{*}{ Treatments } & \multicolumn{4}{|c|}{ AUDPC $^{\mathbf{v}}$} & \multirow[b]{2}{*}{ MS50w $^{w}$} & \multirow[b]{2}{*}{ M50 $^{\mathrm{x}}$} & \multirow[b]{2}{*}{ DI50y } & \multirow[b]{2}{*}{ MDPR $^{\mathbf{z}}$} \\
\hline & 15 December2012 & 1 April 2013 & 15 July 2013 & 1 October 2013 & & & & \\
\hline T1 (daily) & $14.8 \mathrm{a}$ & $26.7 \mathrm{a}$ & $42.8 \mathrm{a}$ & $48.4 \mathrm{a}$ & 57 & 74 & 41 & $0.047 \mathrm{a}$ \\
\hline T2 (weekly) & $0.3 \mathrm{~b}$ & $1.3 \mathrm{~b}$ & $9.7 \mathrm{~b}$ & $13.9 \mathrm{a}$ & & $\ldots$ & 77 & $0.017 \mathrm{a}$ \\
\hline T3 (biweekly) & $0.9 \mathrm{~b}$ & $3.8 \mathrm{~b}$ & $15.7 \mathrm{~b}$ & $21.7 \mathrm{a}$ & 75 & 81 & 74 & $0.021 \mathrm{a}$ \\
\hline $\mathrm{T} 4$ (deficit) & $0.05 \mathrm{~b}$ & $1.8 \mathrm{~b}$ & $9.2 \mathrm{~b}$ & $13.3 \mathrm{a}$ & $\ldots$ & $\ldots$ & 77 & $0.016 \mathrm{a}$ \\
\hline
\end{tabular}

u Values in columns followed by the same letter were not significantly different at $P=0.05$ according to Fisher's protected least significant difference test.

$\vee$ AUDPC $=$ standardized area under the disease progression curve calculated using the trapezoidal integration of severity values expressed as a percentage of the maximum theoretical curve.

${ }^{\mathrm{w}}$ MS50 = time in weeks from planting until the severity of the affected plants was equal to 2.

${ }^{\mathrm{x}} \mathrm{M} 50=$ time in weeks from planting until $50 \%$ of the plants had died.

${ }^{y}$ DI50 $=$ time in weeks from planting until $50 \%$ of the plants were affected.

${ }^{\mathrm{z}}$ Parameter derived from the logistic regression of the severity over time: the maximum disease progress rate (MDPR). 
The epidemic was significantly delayed in Frantoio. The first symptomatic plants were recorded 6 months later than had been observed in Picual and Arbequina. The final DI value in the T1 treatment was 26\%; for other treatments, DI did not reach values greater than $8 \%$ (Table 1; Figs. 1 and 2). In this resistant cultivar, a major increase in the DI occurred during spring 2013. The maximum final values of AUDPC were observed in the T1 trees, which reached $2.1 \%$. Values of this parameter were lower in the $\mathrm{T} 2, \mathrm{~T} 3$, and T4 treatments, accounting for $0.2,1.6$, and $0.6 \%$, respectively. The mean severity of the symptoms remained very low during the recording period. Only $3.7 \%$ of plants were killed by the pathogen at the end of the experiment in one of the treatments (T3) (Table 1).

The largest seasonal increase in DI during the experiment occurred in fall 2012 (23 and 19 trees of the Picual and Arbequina cultivars, respectively, out of 108 trees planted for each cultivar) (Fig. 3). Remarkably, 19 of these trees were from the Picual-T1 treatment
(Fig. 3). In the winter of the second year after planting (2013), the number of newly affected plants was higher in Arbequina (19 trees) than in Picual (10 trees), and the first Frantoio plants ( 2 trees) began to show wilt symptoms. During the second spring, the number of trees affected by VWO was greater in Picual (30 newly affected plants) than in Arbequina (20 trees) and Frantoio (5 trees). When the final DI values were analyzed, only significant differences between cultivars $(P=0.00)$ were found. These values accounted for 72.2, 58.3, and $11.1 \%$ for Picual, Arbequina, and Frantoio, respectively.

Mean disease severity progress curves for Picual and Arbequina were well described by the logistic model (pseudo- $R^{2}>0.98$ ), with the exception of the Picual-T1 treatment. This treatment was described by a logistic model with a double sigmoid pattern (pseudo$R^{2}>0.98$ ). No significant differences in the MDPR were observed in Picual and Arbequina between irrigation frequencies; the average MDPR was significantly higher for Picual plants (0.0254) (Table 2)
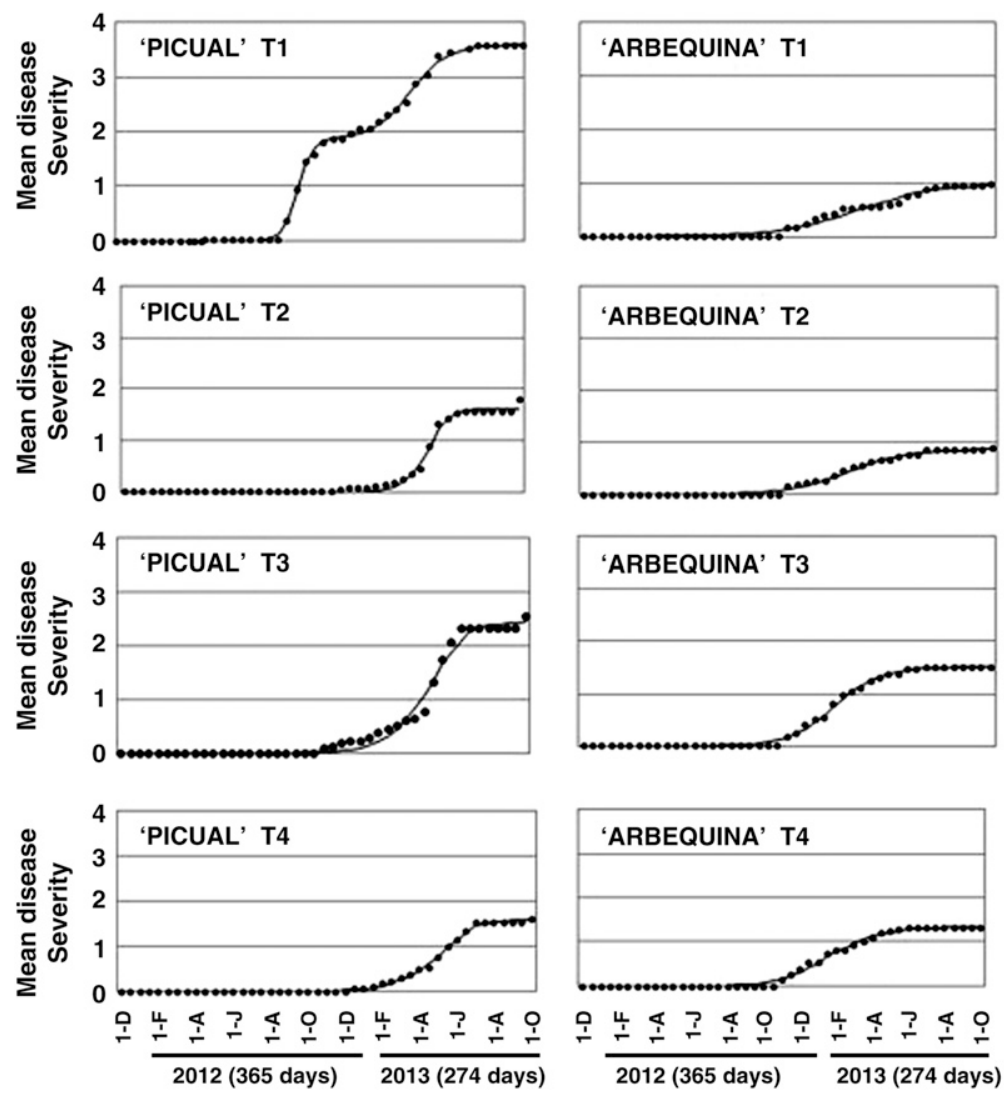
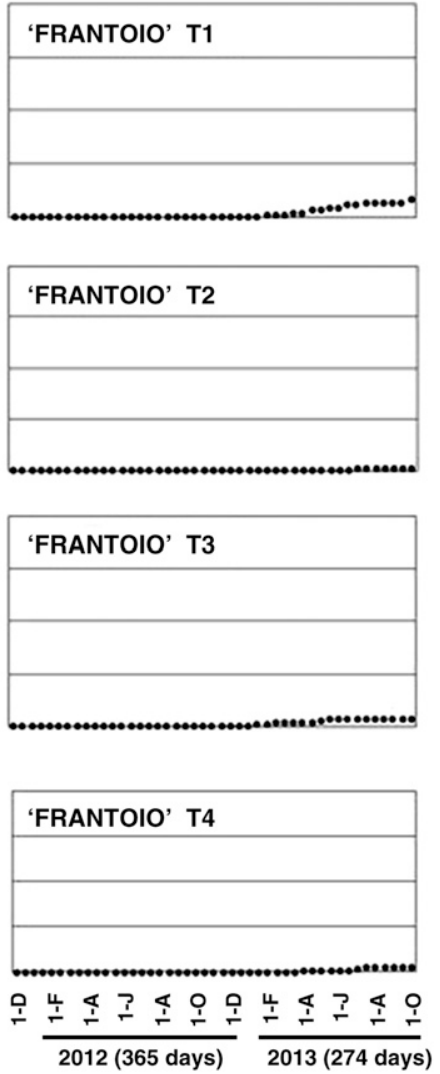

Fig. 2. Mean severity of symptoms of Verticillium wilt over time in Picual (susceptible) Arbequina (moderately susceptible), and Frantoio (resistant) olive in microplots of soil naturally infested with Verticillium dahliae and subjected to four irrigation frequencies: daily (T1), weekly (T2), biweekly (T3), and deficit (T4). Disease severity was estimated on a 0-to-4 rating scale that reflected the percentage of plant tissue affected by any of the following symptoms: chlorosis, necrosis, or defoliation $(0=$ no symptoms; $1=1$ to $33,2=34$ to 66 , and $3=67$ to $99 \%$ affected tissue; and $4=$ dead plant). A severity progression curve of the Picual-T1 treatment was described using a logistic model with a double sigmoid pattern. Other curves were well described using the logistic model. Curves of disease progression for Frantoio could not be fitted to any model.

Table 3. Progression of disease parameters in Arbequina olive trees in microplots of soil naturally infested with Verticillium dahliae subjected to different irrigation frequencies ${ }^{\mathrm{w}}$

\begin{tabular}{|c|c|c|c|c|c|c|}
\hline \multirow[b]{2}{*}{ Treatments } & \multicolumn{4}{|c|}{ AUDPC $^{x}$} & \multirow[b]{2}{*}{ DI50y } & \multirow[b]{2}{*}{ MDPR $^{\mathbf{z}}$} \\
\hline & 15 December 2012 & 1 April 2013 & 15 July 2013 & 1 October 2013 & & \\
\hline T1 (daily) & $1.2 \mathrm{a}$ & $4.7 \mathrm{a}$ & $8.9 \mathrm{a}$ & $11.0 \mathrm{a}$ & 93 & $0.004 \mathrm{~b}$ \\
\hline T2 (weekly) & $1.2 \mathrm{a}$ & $4.4 \mathrm{a}$ & $8.8 \mathrm{a}$ & $10.5 \mathrm{a}$ & 72 & $0.005 \mathrm{~b}$ \\
\hline T3 (biweekly) & $1.8 \mathrm{a}$ & $8.7 \mathrm{a}$ & $16.7 \mathrm{a}$ & $19.7 \mathrm{a}$ & 63 & $0.010 \mathrm{~b}$ \\
\hline $\mathrm{T} 4$ (deficit) & $1.9 \mathrm{a}$ & $7.8 \mathrm{a}$ & $14.8 \mathrm{a}$ & $17.4 \mathrm{a}$ & 67 & $0.009 \mathrm{~b}$ \\
\hline
\end{tabular}

${ }^{\text {w }}$ Values in columns followed by the same letter were not significantly different at $P=0.05$ according to Fisher's protected least significant difference test.

$\mathrm{x}$ AUDPC $=$ standardized area under the disease progression curve calculated using the trapezoidal integration of severity values expressed as the percentage of a maximum theoretical curve.

${ }^{\mathrm{y}} \mathrm{DI}_{50}=$ time in weeks from planting until $50 \%$ of the plants were affected.

${ }^{\mathrm{z}}$ Parameter derived from the logistic regression of the severity over time: the maximum disease progress rate (MDPR). 
than for Arbequina plants (0.0070) (Table 3). The disease progression curves for Frantoio could not be fitted to any model (Fig. 2).

\section{Discussion}

The influence of irrigation frequency on the occurrence and development of Verticillium wilts has been studied in several hosts of Verticillium spp., particularly herbaceous plants (Bletsos et al. 1999; Cappaert et al. 1992, 1994; Jefferson and Gossen 2002; Pennypacker et al. 1991; Wheeler et al. 2012). Similar studies have been scarce in woody crops affected by Verticillium wilts, likely due to the difficulties associated with the experimental design and the length of the observation period necessary to obtain results. Therefore, this research provides novel information about the impact of irrigation schedules in the development of Verticillium wilt in an economically important woody crop, the olive tree. For vascular diseases in which transpiration is one of the major physiological functions affected, an increase in irrigation dose or a shortening in irrigation frequency in the field may support disease development (López-Escudero and Mercado-Blanco 2011). In our trial, the T1, T2, and T3 treatments were established to produce maximum plant growth using different irrigation frequencies. However, the volumetric soil water content in T4 prior to irrigation was below the allowable depletion. Therefore, although it has not been measured, a reduction in transpiration could have occurred only in T4 (Steduto et al. 2012). This would suggest that soil moisture in each treatment played a larger role in disease development than leaf transpiration. In addition, increases in root growth in wet soils could favor contact between susceptible olive roots with infective pathogen structures (Fernández et al. 1991; Huisman 1982; LópezEscudero and Blanco-López 2005; Xiao and Subbarao 2000). This factor needs to be further clarified, so that factors such as the host variety or cultivar or other agronomical aspects may be involved.

The symptoms in the affected trees were similar to those previously described in young olive trees planted in soils naturally infested with the pathogen (Blanco-López et al. 1984; López-Escudero and Blanco-Lopez 2001; Lopez-Escudero and Mercado-Blanco 2011) including dieback, wilting, and slow decline (the defoliation of green leaves and flower death). These symptoms developed on Picual trees under the daily-watered treatment (T1).

Three olive cultivars were chosen based on economic importance and the level of resistance to the pathogen. Worldwide, Picual is the most important variety economically and is susceptible to VWO in both artificial inoculations and field conditions. Arbequina has increased international economic relevance due to adaptation to intensive and hedgerow orchards; it has a similar level of susceptibility as Picual following artificial inoculation but shows moderate susceptibility in field conditions. Frantoio is one of the more important Italian cultivars, and shows a high level of resistance to VWO in both artificial and natural inoculation scenarios (Barranco et al. 2010; LópezEscudero and Mercado-Blanco 2011; Trapero et al. 2013).

The results obtained under the experimental conditions of this study suggest that olive cultivars with diverse levels of resistance to VWO show differential reactions when subjected to differing irrigation frequencies. One of the major conclusions of this work is that a daily irrigation schedule strongly encourages the onset and development of VWO in susceptible Picual olive (Tables 1 and 2; Figs. 1 to 3 ). The final DI values reached $100 \%$ and the AUDPC values remained significantly different from the remainder of the treatments between fall 2012 (14.7\%) and summer 2013 (42.8\%). This effect was not observed in other irrigation frequencies in this cultivar, for which no significant differences were recorded for AUDPC. Meanwhile, disease progress in Arbequina was not influenced by the irrigation frequency, and the AUDPC did not show significant differences between the four treatments over the observed time period (Tables 1 and 3; Figs. 1 to 3), reaching a maximum average value of $14.6 \%$. Finally, the low disease rates recorded for Frantoio clearly suggest that the use of resistant cultivars might have more impact on disease control than the application of certain irrigation frequencies that may be unfavorable for disease development in susceptible cultivars.

The period in which an increase in the number of affected trees occurred was similar among all treatments in Picual and Arbequina; this period started in the fall of the second year after planting (October
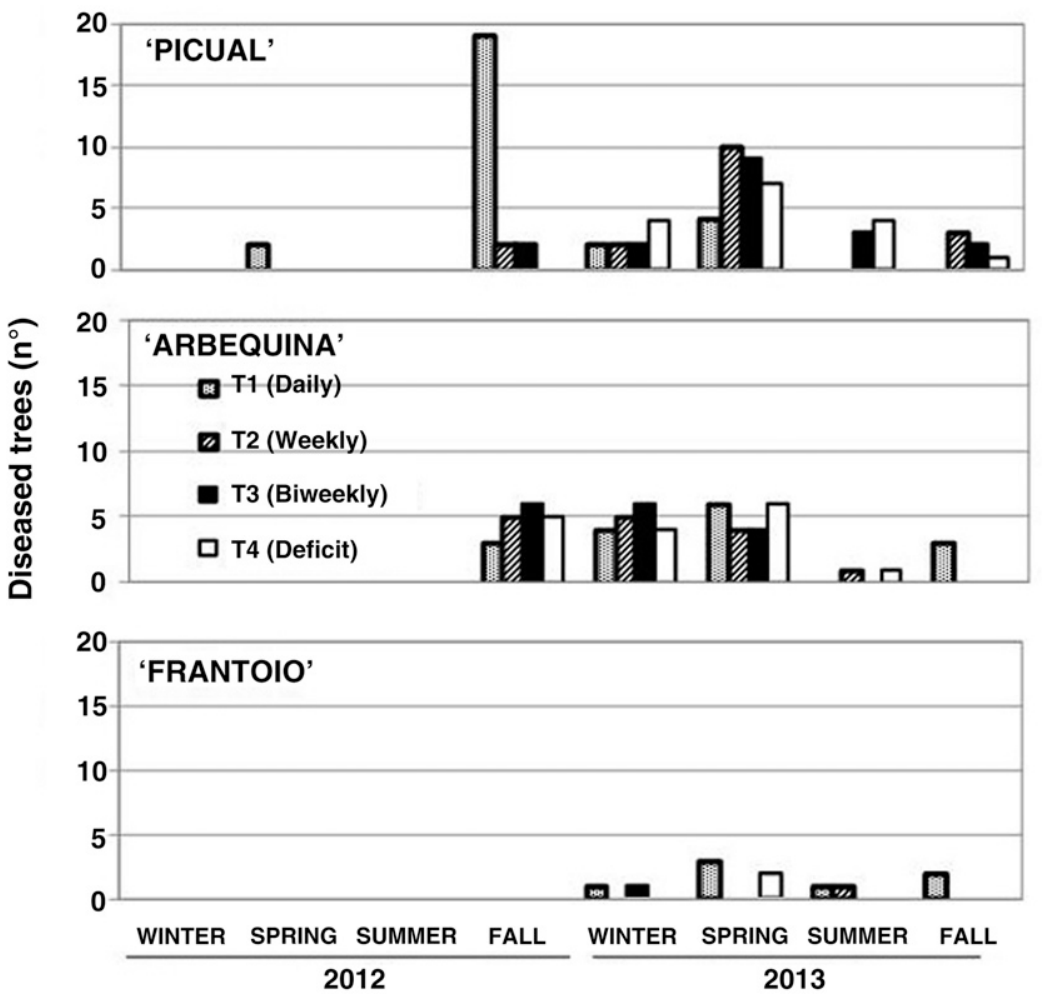

Fig. 3. Number of symptomatic olive trees of Picual (susceptible) Arbequina (moderately susceptible), and Frantoio (resistant) affected by Verticillium wilt in microplots of soil naturally infested with Verticillium dahliae and subjected to four irrigation frequencies: daily (T1), weekly (T2), biweekly (T3), and deficit (T4). 
2012) and peaked at the end of spring 2013 (Table 1; Fig. 1). Disease progression in Picual plants under T1 followed a logistic model with a double-sigmoid pattern; other cultivar-irrigation treatment combinations were fitted to a simple logistic curve (Fig. 2).

VWO incidence in our conditions (southern Spain) increases during two important periods (spring and fall) (López-Escudero and Blanco-López 2001; López-Escudero et al. 2004; Rodríguez-Jurado et al. 1993). A logistic model of a multiple sigmoid pattern has been successfully fitted to the VWO epidemic by Navas-Cortés et al. (2008). Most likely, the influence of daily irrigation has helped encourage disease progression in the Picual-T1 treatment. For other treatments, a longer period of observation than our experimental conditions would be necessary in order to observe the onset and progression of disease.

Several hypotheses could explain the accentuated disease progression in Picual plants under T1 treatment. One of the most reasonable explanations is that plant infection occurred very soon after the establishment of the experiment. In our conditions, high and low temperatures during summer and winter, respectively, usually impede the disease progress; however, root infections could have occurred during the prior spring. In this study, these periods were similar, with some divergence between treatments. In the Picual-T1 treatment, the MDPR after the first summer (2012) was greater than in other treatments, despite not being statistically significant. Subsequently, the AUDPC value increased to $14.8 \%$, compared with an average of $0.4 \%$ for the $\mathrm{T} 2, \mathrm{~T} 3$, and $\mathrm{T} 4$ treatments (Table 2). We conclude that daily irrigation created a more conducive soil environment for the establishment of infection due to a reduction in soil temperature during the summer. This would have also facilitated continuous infections from MS present in the soil and a reduction in the incubation period during the summer months. Karaca et al. (1971) reached similar conclusions; soil temperatures at depths of 5 and $15 \mathrm{~cm}$ in Anatolian cotton fields in July fell 4 to $5^{\circ} \mathrm{C}$ after irrigation, allowing infection to occur. Temperatures registered during the winter of 2012-13 were moderate, which also promotes disease development in general. Another possibility to consider is that the daily irrigation promoted more root development and more root tips, which would increase the number of infection sites.

We assume that other factors are likely also implicated in disease development, including complex interactions involved with cultivar resistance that must be elucidated in new research.

For this study, the observations were finalized in fall 2013. As of May 2013, the maximum number of affected Picual-T1 plants had been reached ( 27 plants), of which $63 \%$ had died. In the remaining treatments, the appearance of newly diseased plants stopped or slowed. A reduction in the DI after the third year was also observed in the studies mentioned above that were conducted in microplots; this was ascribed to the limitations of the microplot system (López-Escudero and Blanco-López 2007). Moreover, the vegetative growth of many plants was excessive by this time and did not allow for correct plant management.

The results from this study strongly encourage a reduction in irrigation frequency when growing very susceptible cultivars in soils containing $V$. dahliae.

\section{Acknowledgments}

This research was funded by a contract between the University of Córdoba and The Spanish Interprofessional Olive Oil Association. (UG 400544). We thank the Oficina Comarcal Agraria "Las Marismas" (Lebrija, Sevilla) and the Sociedad Cooperativa Andaluza "Agroquivir" (Trajano, Sevilla) for their essential participation, for permitting the authors to collect the infested soil necessary for this study from its property, and for their technical assistance; and F. Gonzalez for his persevering technical assistance in the experimental plot.

\section{Literature Cited}

Anonymous. 2013. Anuario de Estadística. Ministerio de Agricultura Alimentación y Medio ambiente. Online publication. http://www.magrama.gob.es.

Arbogast, M., Powelson, M. L., Cappaert, M. R., and Watrud, L. S. 1999. Response of six potato cultivars to amount of applied water and Verticillium dahliae. Phytopathology 89:782-788.
Barranco, D., Fernández-Escobar, R., and Rallo, L. 2010. Olive Growing. Junta de Andalucía/Mundi Prensa/RIRDC/AOA, Pendle Hill, Australia.

Bejarano-Alcázar, J., Blanco-López, M. A., Melero-Vara, J. M., and JiménezDíaz, R. M. 1996. Etiology, importance, and distribution of Verticillium wilt of cotton in southern Spain. Plant Dis. 80:1233-1238.

Blanco-López, M. A., and DeVay, J. E. 1987. Effect of different irrigation regimes on Verticillium wilt, proline content and leaf water potential in cotton. In: Proc. VII Cong. Mediterr. Phytopathol. Union, Granada, Spain.

Blanco-López, M. A., Jiménez-Díaz, R. M., and Caballero, J. M. 1984 Symptomatology, incidence and distribution of Verticillium wilt of olive trees in Andalucía. Phytopathol. Mediterr. 23:1-8.

Bletsos, F. A., Thanassoulopoulos, C. C., and Roupakias, D. G. 1999. Water stress and Verticillium wilt severity on eggplant (Solanum melongena L.). J. Phytopathol. 147:243-248.

Bubici, G., and Cirulli, M. 2011. Verticillium wilt of olives. Pages 191-222 in: Olive Diseases and Disorders. L. Schena, G. E. Agosteo, and S. O. Cacciola, eds. Research Signpost, Kerala, India.

Butterfield, E. J., and Devay, J. E. 1977. Reassessment of soil assays for Verticillium dahliae. Phytopathology 67:1073-1078.

Caballero, J. M., and Del Rio, C. 2008. The olive world germplasm bank of Spain Acta Hortic. 791:31-38

Caballero, J. M., and Del Río, C. 2010. Propagation methods. Pages 83-112 in: Olive Growing. D. Barranco, R. Fernández-Escobar, and L. Rallo, eds. Junta de Andalucía/Mundi Prensa/RIRDC/AOA, Pendle Hill, Australia.

Campbell, C. L., and Madden, L. V. 1990. Introduction to Plant Disease Epidemiology. John Wiley and Sons, New York.

Cappaert, M. R., Powelson, M. L., Christensen, N. W., and Crowe, F. J. 1992. Influence of irrigation on severity of potato early dying and tuber yield. Phytopathology 82:1448-1453.

Cappaert, M. R., Powelson, M. L., Christensen, N. W., Stevenson, W. R., and Rouse, D. I. 1994. Assessment of irrigation as a method of managing potato early dying. Phytopathology 84:792-800.

Fernández, J. E., Moreno, F., Cabrera, F., Arrue, J. L., and Martín-Aranda, J. 1991. Drip irrigation, soil characteristics and the root distribution and root activity of olive trees. Plant Soil 133:239-251.

García-Cabello, S., Pérez-Rodríguez, M., Blanco-López, M. A., and López-Escudero, F. J. 2012. Distribution of Verticillium dahliae through watering systems in widely irrigated olive growing areas in Andalucia (southern Spain). Eur. J. Plant Pathol. 133:877-885.

Harrington, M. A., and Dobinson, K. F. 2000. Influences of cropping practices on Verticillium dahliae populations in commercial processing tomato fields in Ontario. Phytopathology 90:1011-1017.

Hau, B., Amorin, L., and Bergamin Filho, A. 1993. Mathematical functions to describe progress curves of double sigmoid pattern. Phytopathology 83:928-932.

Huisman, O. C. 1982. Interrelationship of root growth dynamics to epidemiology of root invading fungi. Annu. Rev. Phytopathol. 20:303-327.

Huisman, O. C., and Ashworth, L. J. 1974. Quantitative assessment of V. alboatrum in field soils: Procedural and substrate improvements. Phytopathology 64: 1043-1044.

Huisman, O. C., and Grimes, D. W.1989. Cultural practices: The effect of plant density and irrigation regimes on Verticillium wilt of cotton. Pages 537-542 in: Vascular Wilt Diseases of Plants. NATO ASI Ser. H: Cell Biology, vol. 28. E. C. Tjamos and C. H. Beckman, eds. Springer-Verlag, Berlin, Heidelberg.

Jefferson, P. G., and Gossen, B. D. 2002. Irrigation increases Verticillium wilt incidence in a susceptible alfalfa cultivar. Plant Dis. 86:588-592.

Kaplan, E. L., and Meier, P. 1958. Nonparametric-estimation from incomplete observations. J. Am. Stat. Assoc. 53, 282:457-481.

Karaca, I., Karcihoglu, A., and Ceylân, S. 1971. Wilt disease of cotton in the Ege region of Turkey. Page 119 in: Verticillium Wilts. G. F. Pegg and B. L. Brady, eds. CABI Publishing, Trowbridge, UK

López-Escudero, F. J., and Blanco-López, M. A. 2001. Effect of a single or double soil solarization to control Verticillium wilt in established olive orchards in Spain. Plant Dis. 85:489-496.

López-Escudero, F. J., and Blanco-López, M. A. 2005. Effects of drip irrigation on population of Verticillium dahliae in olive orchards. J. Phytopathol. 153:238-239.

López-Escudero, F. J., and Blanco-López, M. A. 2007. Relationship between the inoculum density of Verticillium dahliae and the progress of Verticillium wilt of olive. Plant Dis. 91:1372-1378.

López-Escudero, F. J., Del Río, C., Caballero, J. M., and Blanco-López, M. A. 2004. Evaluation of olive cultivars for resistance to Verticillium dahliae. Eur. J. Plant Pathol. 110:79-85.

López-Escudero, F. J., and Mercado-Blanco, J. 2011. Verticillium wilt of olive: a case study to implement an integrated strategy to control a soil-borne pathogen. Plant Soil 344:1-50.

López-Escudero, F. J., and Mercado-Blanco, J. 2012. Verticillium wilt of olive and its control: The heat is on. Plant Soil 355:17-21.

López-Escudero, F. J., Mercado-Blanco, J., Roca, J. M., Valverde-Corredor, A., and Blanco-López, M. A. 2010. Verticillium wilt of olive in the Guadalquivir Valley (southern Spain): relations with some agronomical factors and spread of Verticillium dahliae. Phytopathol. Mediterr. 49:370-380.

Martos-Moreno, C., López-Escudero, F. J., and Blanco-López, M. Á. 2006. Resistance of olive cultivars to the defoliating pathotype of Verticillium dahliae. HortScience 41:1313-1316. 
Mercado-Blanco, J., Rodríguez-Jurado, D., Parrilla-Araujo, S., and Jiménez-Díaz, R. M. 2003. Simultaneous detection of the defoliating and nondefoliating Verticillium dahliae pathotypes in infected olive plants by duplex, nested polymerase chain reaction. Plant Dis. 87:1487-1494.

Moral, J., and Trapero, A. 2009. Assessing the susceptibility of olive cultivars to anthracnose caused by Colletotrichum acutatum. Plant Dis. 93:1028-1036.

Navas-Cortés, J. A., Landa, B. B., Mercado-Blanco, J., Trapero-Casas, J. L., Rodríguez-Jurado, D., and Jiménez-Díaz, R. M. 2008. Spatiotemporal analysis of spread of infections by Verticillium dahliae pathotypes within a high tree density olive orchard in southern Spain. Phytopathology 98:167-180.

Pennypacker, B. W., Leath, K. T., and Hill, R. R., Jr. 1991. Impact of drought stress on the expression of resistance to Verticillium alboatrum in alfalfa. Phytopathology 81:1014-1024.

Rodríguez, E., García-Garrido, J. M., García, P. A., and Campos, M. 2008. Agricultural factors affecting Verticillium wilt in olive orchards in Spain. Eur. J. Plant Pathol. 122:287-295.

Rodríguez Jurado, D., and Bejarano Alcázar, J. 2007. Dispersión de Verticillium dahliae en el agua utilizada para riego de olivares en Andalucía. Bol. Sanid. Veg. Plagas 33:547-562.
Rodríguez-Jurado, D., Blanco-López, M. A., Rapoport, H. E., and Jiménez-Díaz, R. M. 1993. Present status of Verticillium wilt of olive in Andalucía (southern Spain). Bull. OEPP/EPPO Bull. 23:513-516.

Shufelt, C., and Linderman, R. G.1986. The influence of irrigation on the incidence and severity of Verticillium wilt of Norway maple. Page 50 in: (Abstr.) 4th Int. Verticillium Symp. Guelph, Canada.

Steduto, P., Hisiao, T. C., Fereres, E., and Raes, D. 2012. Crop Yield Response to Water. Food and Agriculture Organization of the United Nations, Rome.

Trapero, C., Serrano, N., Arquero, O., Del Río, C., Trapero, A., and LópezEscudero, F. J. 2013. Field resistance to Verticillium wilt in selected olive cultivars grown in two naturally infested soils. Plant Dis. 97:668-674.

Tsror, L. 2011. Review: Epidemiology and control of Verticillium wilt on olive. Isr. J. Plant Sci. 59:59-69.

Wheeler, T. A., Bordovsky, J. P., Keeling, J. W., Mullinix, B. G., Jr., and Woodward, J. E. 2012. Effects of crop rotation, cultivar, and irrigation and nitrogen rate on Verticillium wilt in cotton. Plant Dis. 96:985-989.

Xiao, C. L., and Subbarao, K. V. 2000. Effects of irrigation and Verticillium dahliae on cauliflower root and shoot growth dynamics. Phytopathology 90: 995-1004. 